\title{
EVALUATION OF NITROGEN AND CALCIUM FOR CONTROL OF HEAD ROT OF BROCCOLI
}

\author{
P.J. WRIGHT \\ Crop \& Food Research, Cronin Road, RD1, Pukekohe, New Zealand \\ Corresponding author: wrightp@crop.cri.nz
}

\begin{abstract}
Bacterial head rot of broccoli caused by Pseudomonas fluorescens and Pseudomonas marginalis $(\mathrm{Pm})$ is a major disease in New Zealand, and there are no effective chemical controls. Overseas reports state that increased $\mathrm{N}$ applications may promote head rot, while foliar applications of Ca may suppress head rot. A small plot field experiment with 5 replicates was carried out at Pukekohe in April 2006. Prior to planting $50 \mathrm{~kg}$ N/ha was applied. There were 12 treatments comprising combinations of three $\mathrm{N}$ treatments (CAN side dressings; 8 weeks after planting; 50,100 or $150 \mathrm{~kg} \mathrm{~N} / \mathrm{ha}$ ) and four Ca treatments: (1) no Ca; (2) pre-plant $\mathrm{CaSO}_{4}$ (gypsum) at $5 \mathrm{t} / \mathrm{ha}$; (3) six foliar applications of Stopit $\left(16 \%\right.$ calcium as $\mathrm{CaCl}_{2}$ ) at 4 litres in 1000 litres water/ha applied at 7-day intervals from early head formation; (4) combination of treatments 2 and 3. A suspension of Pm (ICMP 6039) and Pm (ICMP 8127) (both at $10^{8} \mathrm{cfu} / \mathrm{ml}$ ) was sprayed onto mature broccoli plants to the point of runoff 1 week before disease assessments. The mean head rot incidence was significantly higher $(\mathrm{P}=0.02)$ at $150 \mathrm{~kg} \mathrm{~N} / \mathrm{ha}(22 \%)$ than 50 or $100 \mathrm{~kg} \mathrm{~N} / \mathrm{ha}(15 \%)$. Neither gypsum or Stopit individually reduced head rot, but the combination of both treatments reduced disease incidence from $20 \%$ to $11 \%(\mathrm{P}=0.02)$. Low $\mathrm{N}$ and pre-tillage and foliar $\mathrm{Ca}$ applications gave best control of head rot (5\%).
\end{abstract}

\section{EVALUATION OF COPPER AND SURFACTANTS ON HEAD ROT OF BROCCOLI}

\author{
P.J. WRIGHT \\ Crop \& Food Research, Cronin Road, RD1, Pukekohe, New Zealand \\ Corresponding author: wrightp@crop.cri.nz
}

Bacterial head rot of broccoli, caused by Pseudomonas fluorescens $(P f)$ and Pseudomonas marginalis $(P m)$, is a destructive disease and there are no effective chemical control measures. $P f$ and $P m$ produce biosurfactants that allow the bacteria to penetrate the waxy cuticle of the flower buds. Some commercial surfactants have been reported to increase broccoli head rot susceptibility. This study examined the effects of copper sprays and surfactants on head rot of broccoli. A field experiment with 5 replicates was carried out at Pukekohe in July 2006, using eight treatments comprising combinations of four surfactant treatments (none, Actiwett ${ }^{\circledR}$, DuWett ${ }^{\mathrm{TM}}$ or NuFilm-17 ${ }^{\circledR}$; all $50 \mathrm{ml} /$ 100 litres) and two copper treatments (no copper or copper oxychloride at $400 \mathrm{~g} / 100$ litres at 600 litres/ha). The surfactant/copper treatments were applied to mature broccoli plants 3 day before and 3 days after the heads were sprayed to run-off with a suspension of $P m$ and $P m$ (both at $10^{8} \mathrm{cfu} / \mathrm{ml}$ ). Copper applications did not reduce head rot. The no surfactant treatment had a lower mean incidence $(\mathrm{P}<0.05)$ of head rot $(23 \%)$ compared to Actiwett ${ }^{\circledR}(37 \%)$, DuWett ${ }^{\mathrm{TM}}(35 \%)$ and NuFilm-1 $7^{\circledR}(34 \%)$. The experiment clearly demonstrated that adjuvant surfactants can increase susceptibility of broccoli heads to head rot. It is recommended that growers achieve good control of pests and diseases before the head maturing stage. 